\title{
Quondam castrum Pin w świetle najnowszych badań archeologicznych
}

\section{Quondam castrum Pin in light of recent archaeological excavations}

Zarys treści. Artykuł prezentuje wynik badań archeologicznych prowadzonych w 2008 roku przez Instytut Archeologii UMK w Toruniu w miejscowości Pień. Porusza również kwestie związane $\mathrm{z}$ historią grodu we wczesnym średniowieczu, prezentuje stan badań archeologicznych i historycznych, dotyczących badanej miejscowości oraz hipotezy zakładające prawdopodobną przynależność administracyjną Pnia we wczesnym średniowieczu.

Stowa kluczowe: Pień, quoandam castrum, grodzisko, wczesne średniowiecze, naczynia ceramiczne, Prusowie, państwo pomorskie, ród Powałów, książę pomorski Świętopełk, kasztelania wyszogrodzka.

Miejscowość Pień (gm. Dąbrowa Chełmińska), leżąca w południowo-zachodniej części ziemi chełmińskiej, była w ostatnich latach miejscem intensywnej prospekcji archeologicznej. Rozpoczęte w 2003 roku badania wykopaliskowe pozwoliły na lokalizację kilkunastu stanowisk oraz wykonanie obszerniejszej dokumentacji trzech z nich. Głównym problemem badawczym stało się rozpoznanie pozostałości późnośredniowiecznej siedziby krzyżackiego prokuratora, usytuowanej na kopcu w typie motte, posadowionym na miejscu grodu wczesnośredniowiecznego. W ramach prac wykraczających poza badania powierzchniowe rozpoznano także osadę podgrodową oraz cmentarzysko z poziomem wczesnośredniowiecznych pochówków komorowych.

Pień leży na prawym brzegu Wisły, w obrębie Doliny Fordońskiej, w odległości około $10 \mathrm{~km}$ w dół rzeki od Bydgoszczy (ryc. 1). Grodzisko położone jest w bezpośrednim sąsiedztwie zabudowań znajdujących się niegdyś w składzie majątku ziemskiego Pień, około $250 \mathrm{~m}$ na zachód od drogi gruntowej prowadzącej z Rafy do Ostromecka, na cyplu morenowym w obrębie terasy Wisły. U podnóża 


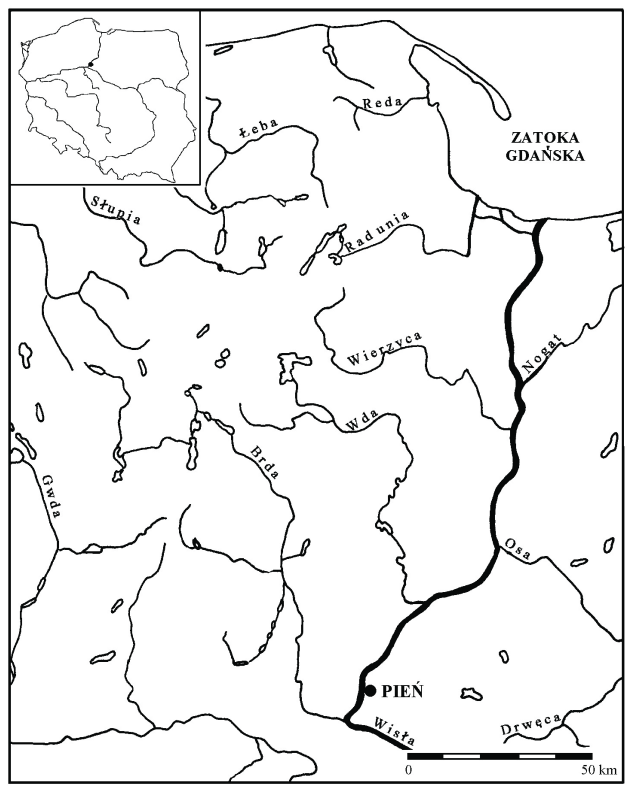

Ryc. 1. Pień, gm. Dąbrowa Chełmińska. Położenie miejscowości (oprac. A. Janowski)

Fig. 1. Pień, Dąbrowa Chełmińska commune. Location of the village (prepared by A. Janowski)

stanowiska znajduje się jezioro Reptówka Duża, będące pozostałością po dawnym nurcie rzeki. Osada leży natomiast przy krawędzi terasy, na wschód i południowy wschód od grodziska (Kola 1991, s. 186; Janowski, Drozd 2005, s. 150; Molewski, Poliński 2006, ryc. 2).

Grodzisko w Pniu budziło zainteresowanie historyków już w XIX wieku za sprawą kilku średniowiecznych dokumentów. Jednym z nich jest tzw. dokument z Lonyz, datowany na 1222 lub 1223 rok, który stanowi nadania księcia mazowieckiego Konrada na rzecz misyjnego biskupa Prus Chrystiana (PrU 1/1, nr 41). W treści dokumentu wymienione są liczne miejscowości, wśród których znajduje się grupa tzw. quondam castra, co tłumaczone jest jako „niegdysiejsze grody". Wśród tych obiektów znajduje się również Pień. Dokument zachował się w dwóch wersjach: krótszej i dłużej, z których tą pierwszą przyjmuje się obecnie za autentyczną (Jasiński 1992; Janowski 2007).

Po raz kolejny Pień został wymieniony w trzech źródłach z połowy XIII wieku. W 1247 roku zakończono wojnę, w której książę pomorski Świętopełk starł się z koalicją książąt polskich, sprzymierzonych z zakonem krzyżackim. W tym samym roku przystąpiono do pertraktacji pokojowych, w których Pień wraz z przyległymi dobrami stał się przedmiotem wymiany między walczącymi stronami. Krzyżacy, dążąc do posiadania całej ziemi chełmińskiej, zaproponowali Świętopełkowi wymianę Pnia, zajętego już wówczas przez koalicję antypomorską, na Lanzanię, krainę leżącą w północnej części Wysoczyzny Elbląskiej oraz gród Zantyr. W myśl tego porozumienia Krzyżacy zgodzili się honorować dożywotnie prawo własności Świętopełka do klucza dóbr z centralnym ośrodkiem w Pniu 
(PUB, nr 96). Kolejne dwa dokumenty z roku 1248 są potwierdzeniem warunków pokojowych, sformułowanych rok wcześniej, z tym wyjątkiem, że książę zrzekł się również ziem uzyskanych na mocy wcześniejszego porozumienia. Powodu tak daleko idących ustępstw ze strony księcia pomorskiego upatruje się w tym, że synowi Świętopełka - Mściwojowi, który przebywał u Krzyżaków w charakterze zakładnika, groziła śmierć. W jednym z tych dokumentów Pień wymieniany jest jako miejsce, gdzie kiedyś istniał gród (PUB, nr 110, 111; O usadownieniu się Krzyżaków 1848, s. 142; Łęga 1956, s. 162; Powierski 2004, s. 69).

Ostatni dokument pochodzący z tego okresu datowany jest na 1285 rok. Mowa w nim o przekazaniu ziemi w majątku Czarże, gdzie dobra w Pniu występują jako jedna $\mathrm{z}$ granic owego nadania (UC, nr 110). W dokumencie tym wymieniona jest również przeprawa wiślana, zlokalizowana w sąsiedniej wsi, leżącej na północ od omawianego kompleksu osadniczego (ryc. 2).

Skromny zasób informacji dotyczących historii miejscowości Pień w XIII wieku, stał się podstawą do szeroko zakrojonej polemiki historyków. Już od początku XX wieku podnoszono w literaturze możliwość ścisłych związków administracyjnych grodu w Pniu z kasztelanią wyszogrodzką (Duda 1909, s. 76-78). Podstawą do tego twierdzenia stał się fakt posiadania tej kasztelanii przez Świętopełka od roku 1232 (Ślaski 1954, s. 101) oraz dokumenty z lat 1247-1248, w których Krzyżacy zgadzają się honorować dożywotnie prawo własności księcia pomorskiego, wysunięte przez niego do miejsca, niegdyś zajmowanego przez gród w Pniu wraz z jego przynależnościami. Problemem stało się natomiast wytłumaczenie okoliczności, w jakich książę nabył prawa do tego skrawka ziemi chełmińskiej.

W literaturze historycznej wysunięto hipotezę, że klucz dóbr z centralnym ośrodkiem w Pniu był od około połowy XII wieku we władaniu rodu Powałów, co w konsekwencji prowadzi do wniosku, że Pień wraz z podległymi mu wsiami znajdował się w dzielnicy mazowieckiej. Założenie to opiera się na stwierdzeniu dziedziczenia na podstawie powinowactwa między księciem pomorskim Samborem I a wojewodą mazowieckim Żyronem, który w XII wieku był właścicielem 26 posiadłości ziemskich w środkowej i północnej części ziemi chełmińskiej (Ślaski 1969, s. 218; Śliwiński 1989, s. 16-17, 20). Nieustaloną kwestią jest natomiast problem statusu prawnego posiadłości chełmińskich Żyrona. W literaturze toczył się spór, czy Pień był własnością dziedziczną, czy beneficjum, przysługującym wojewodzie mazowieckiemu z racji pełnionego urzędu. Wskazuje się jednak, że zarówno Janusz Wojsławic (wzmiankowany jako kasztelan Wyszogrodu w 1145 roku), jak i jego syn Żyron, zarządzali kasztelanią tylko na mocy pełnionych obowiązków (Powierski 1968, s. 117; 1973, s. 20; Bieniak 1970, s. 37; Guldon, Powierski 1974, s. 73; Rymar 1983, s. 27-28). Za przynależnością administracyjną do dzielnicy mazowieckiej klucza dóbr z centralnym ośrodkiem grodowym w Pniu mógłby przemawiać również fakt, że w 1 . połowie XII wieku administratorem tej 


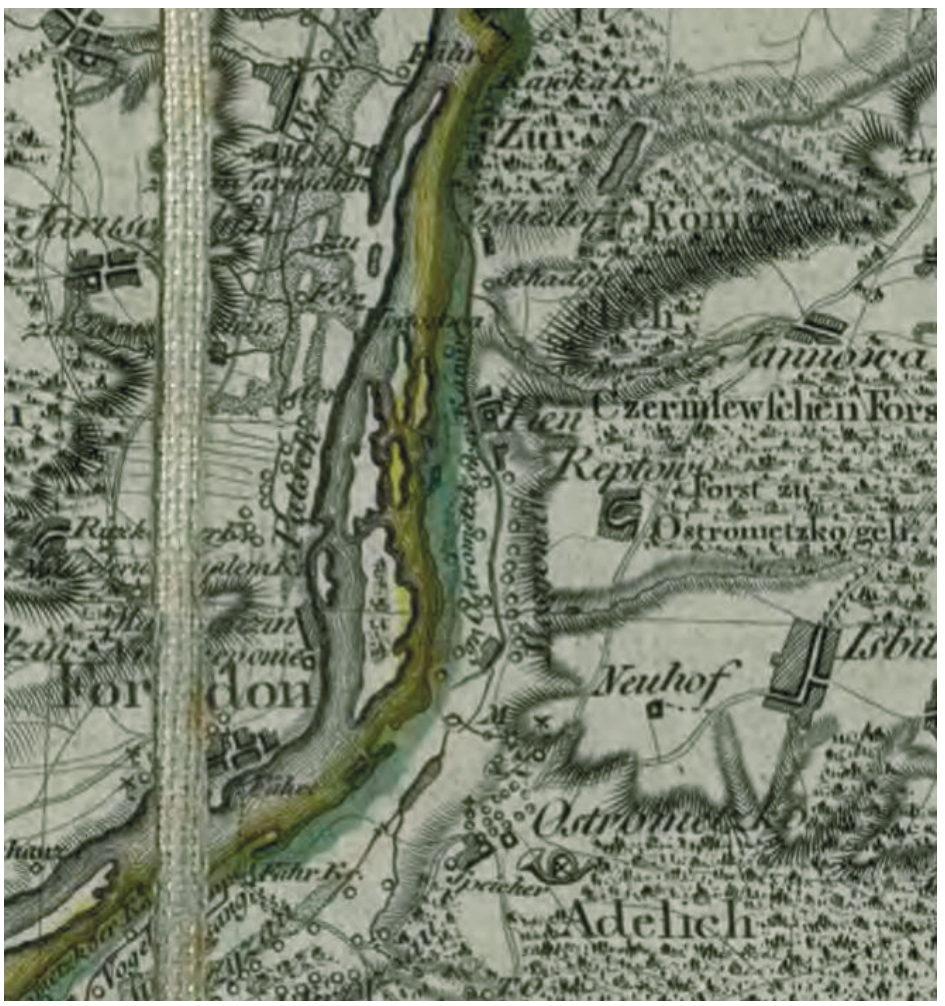

Ryc. 2. Lokalizacja kęp wiślanych w okolicach Pnia (wg Schrötter 1796-1802)

Fig. 2. Location of Vistula holms in the Pień area (after Schrötter 1796-1802)

części ziemi chełmińskiej był Hugon Butyr, określany jako kasztelan. W latach 20. XII wieku administrował on grodem w Kałdusie (Potterbergu), doprowadził do jego odbudowy i kierował wyprawami zbrojnymi skierowanymi na ziemie pruskie. W okolicach Solca Kujawskiego odnotowano także istnienie kępy wiślanej określanej mianem Potirwerder. Pośrednio może to wskazywać na zakres terytorialny administrowania Hugona Butyra, będącego na służbie u Bolesława Kędzierzawego (Powierski 1972, s. 26, 41).

Osobnym problemem stał się los posiadłości Żyrona i rodu Powałów w ziemi chełmińskiej w XIII wieku. Jan Powierski wysunął hipotezę, że w 1222 roku nadając Pień biskupowi Chrystianowi, książę Konrad naruszył prawa własności księcia Świętopełka, co w konsekwencji spowodowało zatarg z księciem mazowieckim o ten majątek. Według prawa Pień należał mu się w spadku po bracie babki, którym był wojewoda Żyron (Powierski 1968, s. 157; 1993, s. 9; 2004, s. 63, 65). Z odmienną propozycją wystąpił Błażej Śliwiński, który wskazał, że Pień mógł znajdować się w części spadku w ziemi chełmińskiej, pozostałym po rodzie Powałów, która po bezpotomnej śmierci jednego z dziedziców pomorskich 
przeszła na Konrada Mazowieckiego. Owym bezpotomnie zmarłym był Subisław II Samborowic († 1217 rok). Zdaniem B. Śliwińskiego miało to dać podstawy Świętopełkowi do prób rewindykacji klucza pieńskiego, który należał mu się w związku z pokrewieństwem z rodem Powałów (Śliwiński 1989, s. 124-126).

Trzecią wersję wydarzeń zaproponował Janusz Bieniak, według którego przekonanie o dziedziczeniu Pnia przez Świętopełka jest błędne i wynika ze złego tłumaczenia tzw. dokumentu z Lonyz. Badacz ten wskazał, że Pień nie jest wymieniony wśród dawnych posiadłości Żyrona, więc identyfikowanie chełmińskich posiadłości Powałów z chełmińskimi posiadłościami Świętopełka jest nieporozumieniem. Argumentem, który miał świadczyć za tezą J. Bieniaka jest fakt, że Świętopełk był krewnym Powałów po kądzieli, a około 1200 roku tego typu prawo spadkowe nie było w państwie polskim powszechne. O nietrwałych prawach księcia pomorskiego do grodu w Pniu miałby świadczyć też dożywotni, a nie dziedziczny charakter własności. Wszystko to wskazywałoby na inne przyczyny roszczeń książąt pomorskich do klucza dóbr w Pniu, który przed 1223 rokiem powrócił w posiadanie Konrada Mazowieckiego (Bieniak 1970, s. 26). O powrocie dóbr Powałów we władanie książąt mazowieckich pisze też Edward Rymar (1983, s. 27).

Ostatnią, ostrożną hipotezą mającą tłumaczyć prawa Świętopełka do Pnia, jest założenie o wcześniejszych związkach klucza pieńskiego z kasztelanią wyszogrodzką. O związkach tego terenu z grodem w Wyszogrodzie mogą świadczyć dane osadnicze i geograficzne. Na podstawie obserwacji informacji osadniczych, założono związek osad w Pniu, Ostromecku, Pędzewie i Czarnowie z położonym po drugiej stronie Wyszogrodem. Kompleks ten był w widoczny sposób oddzielony od wschodu przez lasy i bagna od reszty osadnictwa chełmińskiego, co więcej, stan ten utrzymał się przez kilka kolejnych stuleci. Na całej zaś wschodniej granicy teren przylegał do kasztelanii wyszogrodzkiej (Mader 1960, mapa 1; Powierski 1973, s. 20 - tam dalsza literatura; Powierski, Śliwiński, Bruski 1993, s. 6; Bogucki 1996, s. 96). Związki najstarszego osadnictwa wczesnośredniowiecznego w Pniu z terenami leżącymi po zachodniej stronie Wisły podkreślają też archeolodzy. Analizując najstarsze materiały ceramiczne pozyskane podczas badań w 2007 roku, wysunięto hipotezę o możliwości zasiedlenia tego terenu przez ludność związaną z kompleksem osadniczym w Grucznie (Janowski, Poliński 2008, s. 358).

Położenie grodu na wzniesieniu, u którego podstawy przepływała niegdyś Wisła, może wskazywać na jego kontrolny charakter. Sprawował on najpewniej pieczę nad odcinkiem rzeki, na którym znajdował się bród lub przeprawa, mogąc tym samym być przyczółkiem dla sąsiedniego Wyszogroduํㅜ (Bogucki 1996, s. 98). Oprócz przepraw pod Kałdusem i Solcem Kujawskim znana jest przeprawa znajdująca się w zaginionej miejscowości Kindorff (Kinsdorf), leżąca na prawym brzegu Wisły,

${ }^{1}$ Podobne przypadki, w których zasadnicze terytorium kasztelanii znajduje się po jednej stronie rzeki, zaś niewielkie fragmenty po drugiej, znane są z innych miejscowości w Polsce, na przykład z Wyszogrodu na Mazowszu, Zakroczymia, Sieciechowa, Włocławka, Dobrzynia. 
która miała w 1285 roku graniczyć od południa z Pniem (UC, nr 110). W 1400 roku w miejscowości tej odnotowano istnienie karczmy (Porębska 1971, s. 54), co pośrednio może również świadczyć o lądowym szlaku handlowym, prowadzącym najpewniej na północ lub wschód. O dogodnej przeprawie przez Wisłę w okolicach Pnia mogą świadczyć także archiwalne źródła kartograficzne, które lokalizują tu jedną, a niekiedy kilka dużych kęp wiślanych (Schrötter 1796-1802; Reymann 1845; Porębska 1971, s. 54; Powierski 1972, s. 26) oraz dokumenty z XIV-XV wieku, w których wspomina się o przeprawie w Wyszogrodzie-Fordonie (DKM, nr 45; Lites, s. 61). Z roku 1418 zachowało się natomiast pismo starosty bydgoskiego Janusza Brzozogłowego do komtura toruńskiego Marcina von Kemnate. W treści listu starosta skarżył się na zamknięcie przepraw wiślanych przez urzędników krzyżackich z Torunia, Nieszawy, Świecia i Pnia (Jóźwiak, Szweda 2005, s. 127, 129).

Pierwsze badania archeologiczne, jednak wyłącznie o charakterze rozpoznawczym, przeprowadzono na grodzisku w Pniu na początku lat 40. XX wieku. Niemiecki badacz Irmgard Brutzer zlokalizował obiekt w terenie, charakteryzując całość jako pozostałość grodu późnośredniowiecznego. Dwie dekady później określano je nawet jako grodzisko w typie nordyckim (Heym 1963, s. 311). W kolejnych latach kilkukrotnie weryfikowano stanowisko, zbierając z powierzchni późnośredniowieczny materiał źródłowy (Brutzer 1942, s. 62, 78; Kola 1991, s. 185-186; Janowski 2004). W dalszym ciągu nieznana pozostawała lokalizacja grodziska wczesnośredniowiecznego, wzmiankowanego w źródłach pisanych. W literaturze archeologicznej pojawiło się domniemanie, że zostało ono zmyte przez przepływającą niegdyś u jego podnóża Wisłę (Chudziak 1996, s. 29). Ostatecznie w 2003 roku Alicja Drozd i Andrzej Janowski zlokalizowali pozostałości wczesnośredniowiecznego osadnictwa w obrębie stanowiska nr 1 oraz znajdującej się u jego stóp osady (stanowisko 2).

Na podstawie wyników badań wykopaliskowych, przeprowadzonych w latach 2003-2007 w oparciu o stratygrafię, materiał źródłowy, wyróżniono cztery fazy użytkowania grodu we wczesnym średniowieczu. Pierwszą, przedgrodową wyróżniono na podstawie homogenicznego zbioru materiału ceramicznego (przykrawędnie obtaczanego - GT II), zlokalizowanego poniżej poziomu warstw związanych z budową wału drewniano-ziemnego z kamiennym licem; datowano ją od połowy VII do VIII wieku. Druga faza związana była z budową umocnień, których powstanie datuje się na okres między połową $\mathrm{X}$ wieku a przełomem wieków X i XI. Następne fazy - III i IV - są datowane kolejno na 1. połowę XI wieku oraz 2. połowę XI-XI/XII wieku. W tym przypadku, zarejestrowanych nawarstwień nie dało się powiązać z istniejącymi umocnieniami. Nie natrafiono również na pozostałości młodszych konstrukcji o charakterze obronnym. Na tej podstawie wysunięto hipotezę o istnieniu w tym czasie, w obrębie grodu w Pniu osadnictwa o charakterze otwartym (Janowski, Drozd 2007, s. 207; Janowski, Poliński 2008, s. 352, 357; 2011, s. 492). Z grodziskiem związane jest ściśle 
wczesnośredniowieczne cmentarzysko z grobami komorowymi. Ludzkie szczątki kostne zostały tu zdeponowane w okresie odpowiadającym ramom chronologicznym II fazy osadniczej (Drozd, Janowski, Poliński 2009, s. 355).

Badania archeologiczne przeprowadzone w 2008 roku były kontynuacją prac wykopaliskowych z lat 2003-2007, których głównym zamierzeniem stało się kompleksowe rozpoznanie pozostałości krzyżackiego obiektu mieszkalno-obronnego, zlokalizowanego na kopcu (ryc. 3). Założono wówczas dwa wykopy: jeden (wykop 9/08), o wymiarach $5 \times 5 \mathrm{~m}$, w południowej części stożka, drugi (wykop 10/08) o wymiarach $4 \times 2 \mathrm{~m}$, na zachodnim skłonie stożka. W pierwszym spodziewano się uchwycić przebieg południowej ściany obiektu oraz zlokalizować przybudówkę z ewentualnym wejściem. Drugi zaś wytyczono w celu zweryfikowania nawarstwień kulturowych u styku grodziska wczesnośredniowiecznego i późnośredniowiecznego kopca.

Dodatkowo wykonano również szereg odwiertów, mających na celu weryfikację nawarstwień w obrębie dawnej fosy (Poliński 2008). Łącznie przebadano obszar o powierzchni $33 \mathrm{~m}^{2}$. W trakcie badań pozyskano bogaty zbiór źródeł ruchomych: 3768 fragmentów naczyń ceramicznych (w tym 2676 wczesnośredniowiecznych, 1088 późnośredniowiecznych i 3 fragmenty pradziejowych), 91 fragmentów kafli garnkowych, 4 fragmenty ceramiki budowlanej oraz 2117 fragmentów kości zwierzęcych. Pozyskano poza tym 138 zabytków tzw. wydzielonych, wśród których znajduje się 111 przedmiotów związanych z pozostałościami krzyżackiego budynku mieszkalno-obronnego, pozostałe zaś pozyskano z warstw związanych z nasypem kopca oraz z warstw wczesnośredniowiecznych, zarejestrowanych w wykopie 10/08 (Poliński 2008).

Miąższość nawarstwień kulturowych w wykopie 9/08 wynosiła miejscami $3 \mathrm{~m}$ (ryc. 4). W trakcie eksploracji udało się zarejestrować przebieg ściany południowej obiektu o późnośredniowiecznej chronologii, rejestrując dwa rzędy słupów pod wkop fundamentowy. Nawarstwienia późnośredniowieczne zalegały do głębokości około $80 \mathrm{~cm}$, jednak w miejscach nabijania pali sięgały niekiedy $2 \mathrm{~m}$. W trakcie eksploracji nawarstwień wczesnośredniowiecznych pozyskano 234 fragmenty naczyń ceramicznych (głównie fragmentów naczyń częściowo obtaczanych), kilkanaście fragmentów zalegających w warstwach związanych z budową krzyżackiej warowni oraz dwa przęśliki ceramiczne. Niezwykle interesującymi znaleziskami są dwie ostrogi: żelazna, odkryta w warstwie II i brązowa, odkryta w warstwie XXI. Ostroga żelazna datowana jest na połowę VII-VIII wieku, natomiast brązowa na 2. połowę VIII wieku. Niestety, oba przedmioty znaleziono w warstwach nasypiskowych (żelazna w warstwie pod humusem, brązowa w nawarstwieniach związanych z budową wału), których nie należy utożsamiać z czasem ich wykonania (Janowski 2010, s. 173-175, 180). Poza ostrogami znaleziono też nowożytny medalik z wizerunkiem Michała Archanioła, jednak jego zaleganie na wtórnym złożu nie pozwala na dokładniejsze ustalenie chronologii. 


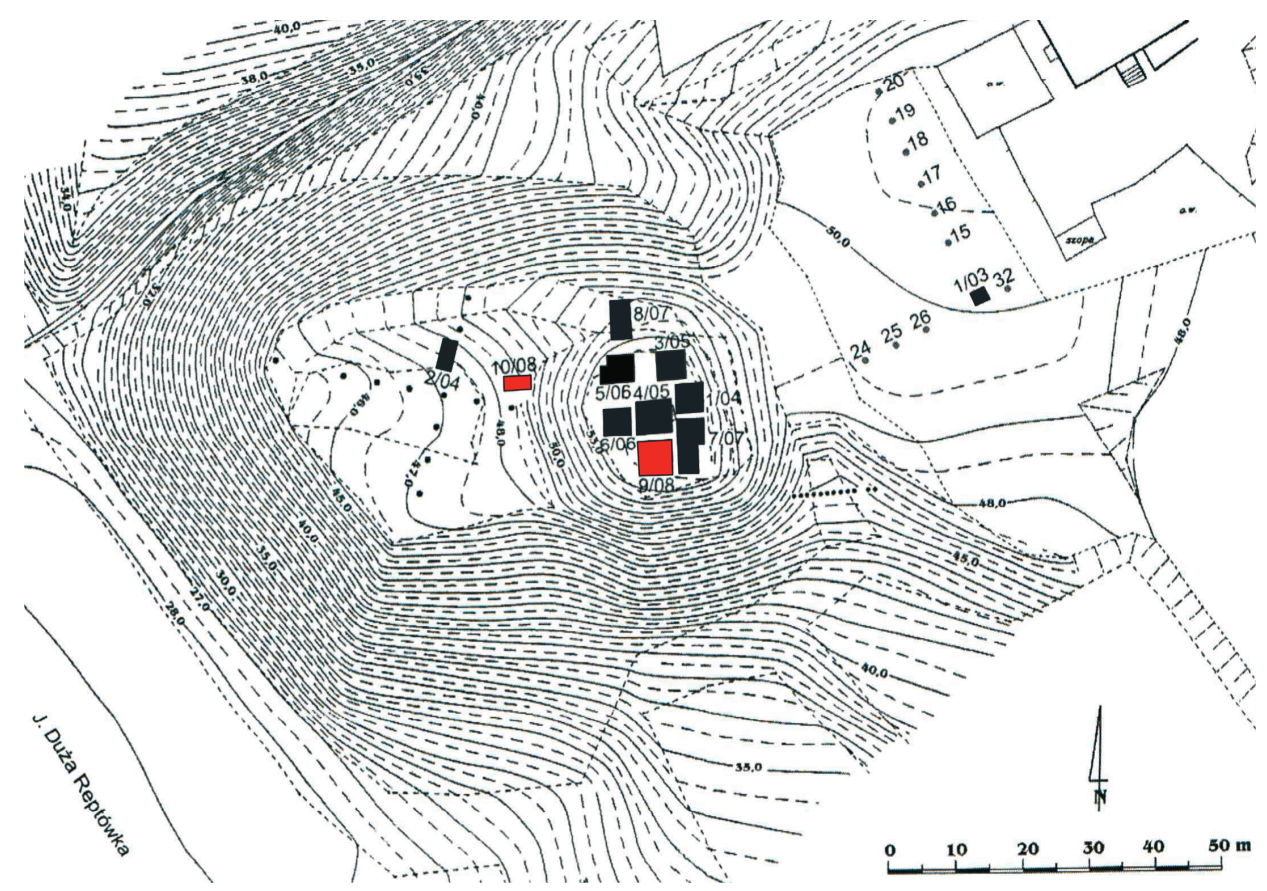

Ryc. 3. Pień, gm. Dąbrowa Chełmińska, stanowisko 1. Plan grodziska z zaznaczonymi wykopami z lat 2004-2008. Kolorem czerwonym oznaczono wykopy założone w 2008 roku (rys. A. Janowski)

Fig. 3. Pień, Dąbrowa Chełmińska commune, site 1. Plan of the stronghold with trenches marked from 2004-2008. Red indicates trenches started in 2008 (drawing A. Janowski)

Wykop 9/08 dostarczył także danych, związanych z budową wału obronnego datowanego na 1. połowę X-X/XI wieku. Warstwy XIX, XXI, XXII i XXIV stanowiły pozostałości po kolejnych etapach wznoszenia umocnień. W obrębie warstw XIX i XXI zaobserwowano pozostałości faszynowania, mającego wzmocnić tę część nasypu (ryc. 4). W warstwie XIX stwierdzono również pozostałości licowania wału drewnem. Analiza materiału ceramicznego pozyskanego z opisywanych nawarstwień wałowych wskazuje na poprawność dotychczasowych ustaleń chronologicznych (połowa X-X/XI wieku), dotyczących momentu wzniesienia umocnień. Oprócz fragmentów naczyń ceramicznych z warstw związanych w wałem wczesnośredniowiecznym wydobyto kilkaset kości zwierzęcych.

W obrębie wykopu 10/08, zlokalizowanego niemal w środku majdanu wczesnośredniowiecznego grodziska, miąższość nawarstwień kulturowych wynosiła 3,5 m (ryc. 5). Do głębokości $90 \mathrm{~cm}$ zalegały nawarstwienia związane z krótkotrwałą, późnośredniowieczną fazą osadniczą; zarejestrowano w ich między innymi pozostałości kamionki typu Siegburg oraz srebrny szeląg Michała Küchmeistera, 


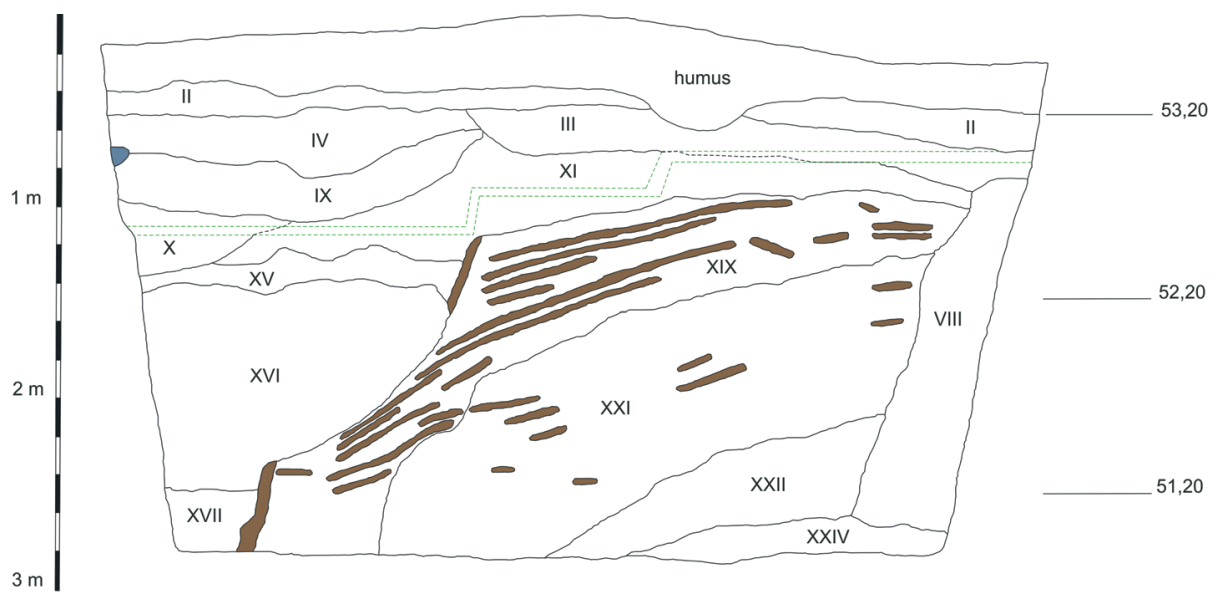

Ryc. 4. Pień, gm. Dąbrowa Chełmińska, stanowisko 1. Profil południowy wykopu 9/08 (rys. P. Gorący, oprac. P. Miernik)

Fig. 4. Pień, Dąbrowa Chełmińska commune, site 1. South section of trench 9/08 (drawing P. Gorący, prepared by P. Miernik)

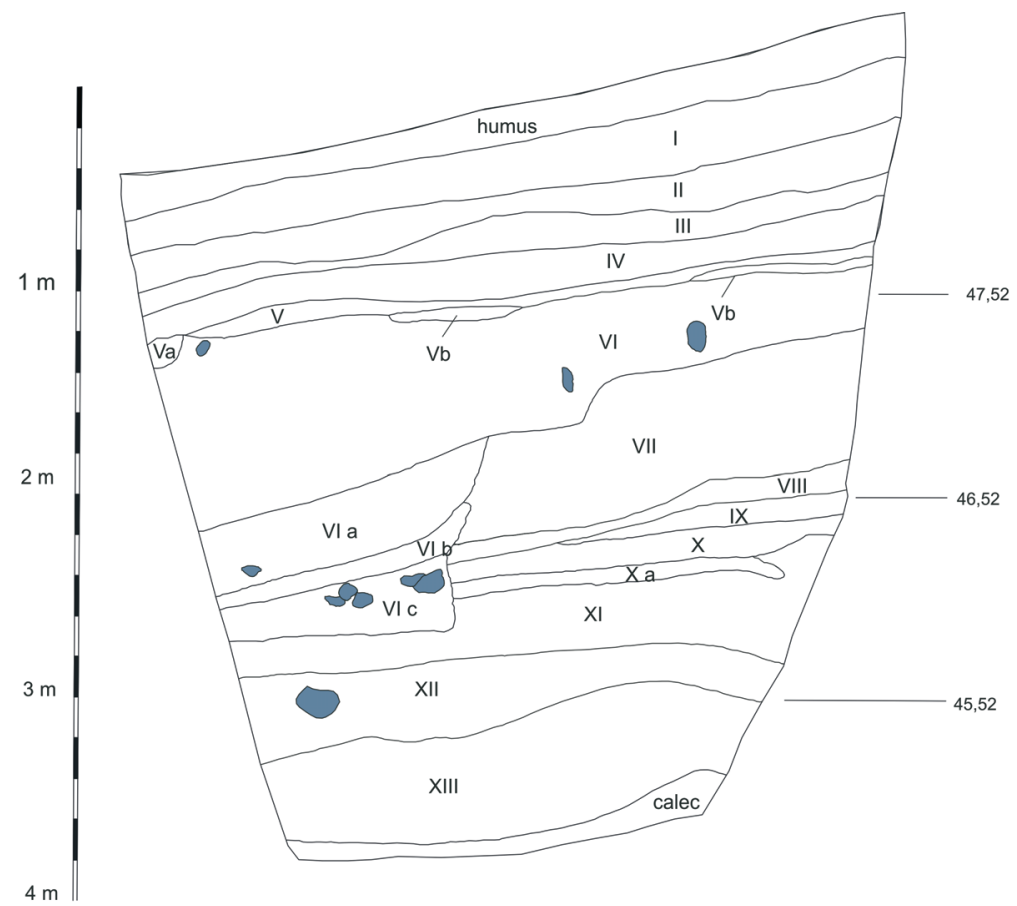

Ryc. 5. Pień, gm. Dąbrowa Chełmińska, stanowisko 1. Profil północny wykopu 10/08 (rys. D. Tkocz, oprac. P. Miernik)

Fig. 5. Pień, Dąbrowa Chełmińska commune, site 1. North section of trench 10/08 (drawing D. Tkocz, prepared by P. Miernik) 
datowany na lata 1413-1422. Poniżej, do głębokości 3,5 m, występowały warstwy o chronologii wczesnośredniowiecznej. Granicę między nimi stanowiły nawarstwienia $(\mathrm{V}-\mathrm{Vb})$, które zawierały znaczne ilości spalenizny. Zarejestrowano w nich zarówno wczesno-, jaki i późnośredniowieczny materiał ceramiczny, co do końca nie wyklucza możliwości ich powstania we wczesnym średniowieczu. Najprawdopodobniej powstały one w chwili zniszczenia obiektu. Bezpośrednio nad opisanymi jednostkami stratygraficznymi znajdowała się warstwa żółtego, sypkiego piasku, będąca pozostałością niwelacji terenu, wykonanej przez Krzyżaków w 1. ćwierci XV wieku.

Poniżej nawarstwień późnośredniowiecznych w wykopie 10/08 zarejestrowano pozostałości wczesnośredniowiecznego obiektu, być może o charakterze mieszkalnym. Miąższość tych nawarstwień wynosiła około $140 \mathrm{~cm}$; w ich obrębie, poza licznymi fragmentami naczyń ceramicznych (faza IV rozwoju garncarstwa chełmińskiego) znaleziono również kamienny przęślik, srebrną monetę, żelazny nożyk oraz stożkową, wykonaną z kości oprawę rękojeści noża. Ze względu na rozpoznanie jedynie niewielkiej powierzchni obiektu mieszkalnego, trudno wnioskować o jego wymiarach. Na podstawie analizy materiału ceramicznego można go wiązać z IV fazą osadniczą, przypadającą na XI/XII wieku. O istnieniu w tej części grodu budynku - być może wzniesionego w konstrukcji słupowej - mogą również świadczyć zagłębienia po drewnianych palach. Warstwy VIa-VIc są zapewne pozostałością po podpiwniczeniu opisanego obiektu (ryc. 5, 6).

Warstwy związane z opisanym obiektem niszczyły nawarstwienia datowane na III fazę osadniczą grodu (warstwy VIII-XI). W ich obrębie zarejestrowano 284 fragmenty wczesnośredniowiecznych naczyń ceramicznych, wykonanych w technologii częściowego (GT III) oraz całkowitego obtaczania (GT V), z przewagą tej drugiej grupy (ryc. 5).

Z II fazą osadniczą należy wiązać warstwy XII i XIII. Pierwsza z nich składała się z ciemnoszarego piasku z dużą zawartością węgli drzewnych i popiołu, natomiast warstwa XIII z luźnego ciemnoszarego piasku przemieszanego z popiołem. $\mathrm{Z}$ obu warstw wydobyto 806 fragmentów naczyń ceramicznych, wykonanych przeważnie w technice częściowego obtaczania (GT III). Analiza stylistyczna pozwala datować ten zbiór naczyń na 2. połowę X-X/XI wieku (ryc. 7). Określenie funkcji wymienionych nawarstwień jest niezwykle problematyczne. W trakcie eksploracji zaobserwowano, że warstwa XIII posiada liczne, poziome warstewki spalenizny, co świadczyłoby o systematycznym odkładaniu się pozostałości procesów spalania. Obecność bardzo dużej liczny fragmentów naczyń ceramicznych może wskazywać, iż w tym miejscu wypalano naczynia (?).

Pozyskane źródła pozwoliły na wyróżnienie czterech faz osadnictwa wczesnośredniowiecznego, datowanych na połowę X-XI/XII wieku oraz fazy późnośredniowiecznej, datowanej na 1. ćwierć XV wieku. Podobnie jak w poprzednich sezonach badawczych, nie zarejestrowano pozostałości osadnictwa, które można 

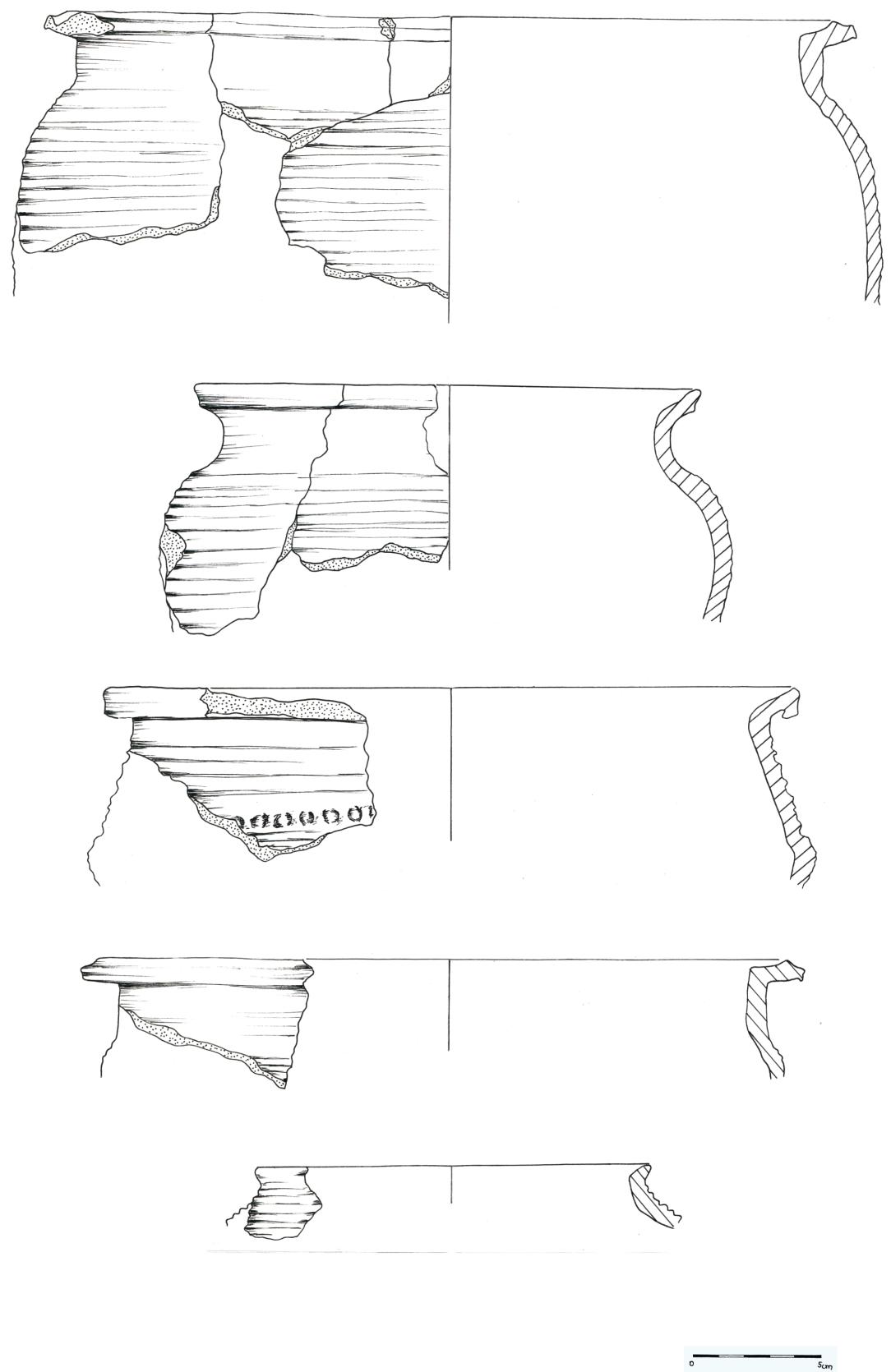

Ryc. 6. Pień, gm. Dąbrowa Chełmińska, stanowisko 1. Fragmenty naczyń ceramicznych odkryte w nawarstwieniach IV fazy osadniczej (rys. M. Pioś)

Fig. 6. Pień, Dąbrowa Chełmińska commune, site 1. Fragments of pottery discovered in the layers of settlement phase IV (drawing M. Pioś) 

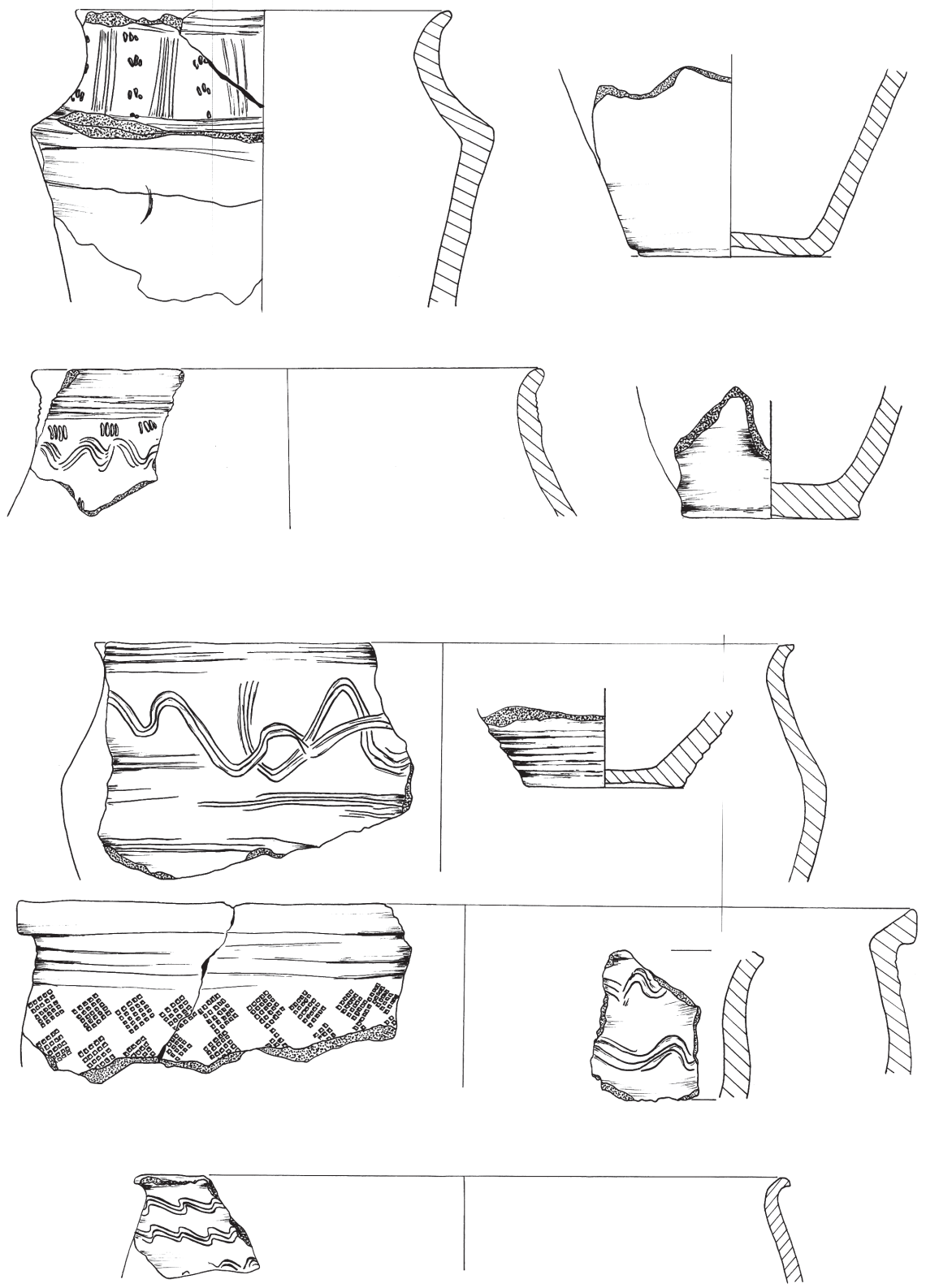

Ryc. 7. Pień, gm. Dąbrowa Chełmińska, stanowisko 1. Fragmenty naczyń ceramicznych odkryte w nawarstwieniach II fazy osadniczej (rys. M. Pioś)

Fig. 7. Pień, Dąbrowa Chełmińska commune, site 1. Fragments of pottery discovered in the layers of settlement phase II (drawing M. Pioś) 
by datować na wiek XIII, co jeszcze bardziej uwiarygodnia przekonanie, że quondam castrum Pin w chwili nadania na rzecz biskupa Chrystiana było istotnie grodziskiem. Nadal nierozstrzygniętą kwestią jest natomiast przynależność administracyjna grodu, który znajdował się w mazowiecko-pomorskiej strefie przygranicznej. Kwestią otwartą pozostaje również pytanie, która ze stron stoi za zniszczeniem obiektu. Intensyfikacja działań zbrojnych w tej części ziem polskich w 1. ćwierci XII wieku była na tyle duża, że nie da się w jednoznaczny sposób odpowiedzieć na to pytanie. Starsze opracowania historyczne tłumaczą zniszczenie Pnia przez któryś z licznych najazdów pruskich, gnębiących ziemię chełmińską w XIII wieku. Wielokrotnie podkreślano znaczenie tego ośrodka grodowego, jako jednego z wielu strzegących Kulmię przed najazdami rabunkowymi Prusów (Narbutt 1837, s. 500; Szulc 1844, s. 500). Wysunięto również hipotezę, że Pień, obok Potterbergu i Grudziądza, był jednym z najważniejszych elementów zorganizowanego systemu obrony, który uzupełniały inne quondam castra wymienione w tzw. dokumencie z Lonyz (Zakrzewski 1902, s. 242-243). Również J. Powierski wskazuje na Prusów jako odpowiedzialnych za zniszczenie grodu i fakt ten przypisuje ewentualnym zmianom granic między kasztelanią chełmińską a wyszogrodzką (Powierski 1973, s. 19-20). Ustalenia te nie zgadzają się jednak z wynikami badań archeologicznych, które przesuwają moment zniszczenia grodu w Pniu na początek wieku XII. Nie znaczy to jednak, że za zniszczeniem obiektu nie mogą stać Prusowie, którzy zapewne już w tym czasie mogli zapuszczać się na terytorium ziemi chełmińskiej. Za taką hipotezą może świadczyć, odnotowana przez Galla Anonima, wyprawa Bolesława Krzywoustego na ziemie Sasinów wiosną 1108 roku, będąca zapewne wyprawą odwetową za pomoc, jaką lud ten miał udzielić bratu Bolesława Krzywoustego - Zbigniewowi (Powierski 1968, s. 101).

Drugą możliwością jest najazd Pomorzan (być może w sojuszu z Prusami) na ziemię chełmińską na początku XII wieku. Przyjmując założenie, że ziemia chełmińska była związana z Mazowszem i co za tym idzie z państwem polskim już od XI wieku (Powierski 1968, s. 19; Chudziak 1997, s. 17; 1999, s. 144) oraz teorię wskazującą granicę między Pomorzem a dzielnicą polską na Wiśle, można założyć, że taki najazd był możliwy. Wyprawy Bolesława Krzywoustego do Prus i na Pomorze, dokonywane na przemian, mogą świadczyć o jakiejś formie współdziałania tych dwóch stron (Powierski 1968, s. 104). Wymienione w tzw. dokumencie z Lonyz quondam castra znajdują się w głównej mierze w bezpośrednim sąsiedztwie Wisły (Pień, Kałdus, Gzin, Grudziądz) lub w kilkunastokilometrowym oddaleniu od rzeki. Badania archeologiczne wykazały, że niemal wszystkie z tych grodów zostały zniszczone lub opuszczone w początku XII wieku, a jedynie Potterberg odbudowano za sprawą Hugona Butyra (Powierski 1972, s. 41; Bojarski 1994, s. 142; Tokarski 1994, s. 97). Uwzględniając lokalizację zniszczonych grodów można założyć, że wyprawa Pomorzan była możliwa, zważywszy na podobne 
wypady Bolesława Krzywoustego na przygraniczne grody pomorsko-wielkopolskie. W przypadku tej teorii porzucenie grodów (lub zarzucenie odbudowy) przez stronę polską (w tzw. dokumencie z Lonyz - totaliter desolatum) spowodowane było zapewne przesunięciem zachodniej granicy rządzonego przez Bolesława Krzywoustego państwa, powiększonego o Pomorze Wschodnie zdobyte w latach 1115-1119 (Maleczyński 1975, s. 148), a także centralizacją władzy w największych ośrodkach rejonu (Chudziak 1999, s. 148). W nowych okolicznościach nie było potrzeby utrzymywać tak licznej sieci grodów, leżących wewnątrz jednego organizmu państwowego. Obiekt w Potterbergu nadal funkcjonował jako ośrodek centralny, kontrolujący trakty handlowe (Chudziak 1997, ryc. 1), zarówno wodne (koryto Wisły), jak i lądowe (w kierunku Drohiczyna).

Trzeci wariant zakłada możliwość przynależności grodu w początkach XII wieku do terytorium pomorskiego, jako punktu obrony przy przeprawie wiślanej. Zniszczenie obiektu należałoby wtedy przypisać wojskom Bolesława Krzywoustego. Spalenie grodu można w tym przypadku umieścić około roku 1113, kiedy to Bolesław Krzywousty oblegał Wyszogród, leżący kilka kilometrów od Pnia. Przyjmując hipotezę o pomorskiej przynależności Pnia należy założyć, że wojska księcia polskiego nie mogły sobie pozwolić na pozostawienie po drugiej stronie rzeki grodu, z którego w każdej chwili mogły nadejść posiłki dla oblężonych. W takim wypadku, w szerszym ujęciu, z ośrodkiem w Pniu należałoby wiązać grody, leżące na pewno w początkach XII wieku w obrębie terytorium pomorskiego, między innymi obiekty w Bydgoszczy, Strzelcach Dolnych i Pawłówku. Kres ich istnienia, na podstawie datowania materiału ceramicznego, umieszcza się na przełomie XI i XII wieku lub na początku XII stulecia (Leciejewicz 1959, s. 128; Wilke, Potemski 1985, s. 12, 17; Chudziak, Bojarski 2007; Błędowski 2012).

Wyniki badań archeologicznych w Pniu dostarczyły ważnych informacji na temat chronologii zasiedlenia tej części ziemi chełmińskiej. Zawiłość procesów dziejowych w rejonie dawnego pogranicza mazowiecko-prusko-pomorskiego, mających miejsce w 1 . ćwierci XII wieku, nie pozwala w jednoznaczny sposób wskazać na przynależność administracyjną ośrodka grodowego w Pniu. Można jednak przypuszczać, że miejscowość ta znajdowała się w orbicie wpływów książąt pomorskich. Pień, jak i zapewne jeszcze kilka grodów chełmińskich, został zniszczony najprawdopodobniej na skutek działań wojennych prowadzonych między księciem polskim Bolesławem, księciem pomorskim Świętopełkiem oraz plemionami pruskimi. 


\section{Bibliografia}

\section{Źródla pisane}

DKM - Dokumenty kujawskie i mazowieckie przeważnie z XIII wieku, wyd. B. Ulanowski, Kraków 1887.

Lites - Lites ac res gestae inter Polonos ordinemque Cruciferorum, t. 2, Poznań 1891.

PrU - Preussisches Urkundenbuch, t. 1, z.1, oprac. A. Philippi, Königsberg-Marburg 1882.

PUB - Pommerellisches Urkundenbuch, wyd. M. Perlbach, Danzig 1882.

UC - Urkundenbuch des Bisthums Culm, oprac. C. P. Woelky, Danzig 1885.

\section{Źródła kartograficzne}

Reymann D.

1845 Topographische Specialkarte des Preussischen Staats und der angrenzenden Länder, b.m.w.

Schrötter F.

1796-1802 Karte von Ost-Preussen nebst Preussisch Litthauen und West-Preussen nebst dem Netzdistrict, Berlin.

\section{Literatura}

Bieniak J.

1970 Studia nad dziejami ziemi chetmińskiej w okresie piastowskim, Rocznik Grudziądzki, t. 5/6, s. 5-69.

Błędowski P.

2012 Sprawozdanie $\mathrm{z}$ badań ratowniczych przeprowadzonych na wczesnośredniowiecznej osadzie w Pawłówku, gm Sicienko (stanowisko 11) w roku 2012, maszynopis w Instytucie Archeologii UMK, Torun.

Bogucki A.

1996 Kasztelanie nad dolna Brda w XII i XIII wieku, Roczniki Historyczne, R. 62, s. $89-113$.

Bojarski J.

1994 Wczesnośredniowieczne grodzisko w Wabczu na ziemi chetmińskiej, [w:] Studia nad osadnictwem wczesnośredniowiecznym ziemi chetmińskiej. Wybrane zagadnienia i materiały, red. J. Olczak, Toruń, s. 111-152.

Brutzer I.

1942 Neueingänge und Fundnachrichten im Berichtsjahr 1941, Gothiskandza. Blätter für Westpreußische Vorgeschichte, z. 4, s. 47-48. 
Chudziak W.

1996 Quondam castra wświetle badań wczesnośredniowiecznych grodzisk ziemi chetmińskiej, Archaeologia Historica Polona, t. 3, s. 25-34.

1997 Wczesnośredniowieczny szlak komunikacyjny z Kujaw do Prus-studium archeologiczne, [w:] Wczesnośredniowieczny szlak lądowy z Kujaw do Prus (XI wiek). Studia i materiaty, red. W. Chudziak, Toruń, s. 9-32.

1999 Geneza i rozwój wczesnośredniowiecznych grodów w strefie chetmińsko-dobrzyńskiej, [w:] Studia nad osadnictwem wczesnośredniowiecznym ziemi chetmińskiej, red. J. Olczak, Toruń 1999, s. 137-158.

Chudziak W., Bojarski J.

2007 Sprawozdanie z badań przeprowadzonych we wschodniej partii wczesnośredniowiecznego grodziska w Bydgoszczy, stanowisko 1. Wstępne wyniki badań, maszynopis w Instytucie Archeologii UMK, Toruń.

Duda F.

1909 Rozwój terytoryalny Pomorza polskiego (wiek XI-XII), Kraków.

Drozd A., Janowski A., Poliński D.

2009 Wczesnośredniowieczne groby komorowe na cmentarzysku w Pniu koło Bydgoszczy (badania 2005-2007), [w:] XVI Sesja Pomorzoznawcza, Szczecin 22-24 listopada 2007 r., cz. 1: Od epoki kamienia do okresu wczesnośredniowiecznego, red. A. Janowski, K. Kowalski, S. Słowiński, Acta Archaeologica Pomoranica, t. 3, Szczecin, s. 351-366.

Guldon Z., Powierski J.

1974 Podziaty administracyjne Kujaw i ziemi chetmińskiej w XIII-XIV wieku, Warszawa-Poznań.

Heym W.

1963 Frühe Burgen des Culmerlandes. Ein Beitrag zu den Burgen, die im Vertrag von Lonyz 1222 , quondam castrum” genannt werden, Jahrbuch der Albertus-Universität zu Königsberg/Pr., t. 13, s. 307-320.

Janowski A.

2004 Grody nadwiślańskie na Pomorzu Wschodnim we wczesnym średniowieczu, maszynopis pracy doktorskiej w Instytucie Archeologii UMK, Toruń.

2007 Quandam castrum Ruth-próba lokalizacji średniowiecznego grodu w ziemi chetmińskiej $w$ świetle źródet pisanych i archeologicznych, Archaelogia Historica Polona, t. 17, s. 277-292.

2010 Dwie ostrogi z zaczepem haczykowato zagiętym do wnętrza z miejscowości Pień na ziemi chetmińskiej, Acta Militaria Mediaevalia, t. 6, s. 173-183.

Janowski A., Drozd A.

2005 Grodzisko późnośredniowieczne (stan. 1) i osada wczesnośredniowieczna (stan. 2) w miejscowości Pień, gm. Dąrowa Chetmińska, województwo kujawsko-pomorskie, [w:] XIV Sesja Pomorzoznawcza, t. 2: Od wczesnego średniowiecza do czasów nowożytnych, red. H. Paner, M. Fudziński, Gdańsk, s. $147-155$. 
2007 Grodzisko wczesnośredniowieczne w Pniu woj. kujawsko-pomorskie w świetle badań w latach 2004-2005, [w:] XV Sesja Pomorzoznawcza, red. G. Nawrolska, Elbląg, s. 199-209.

Janowski A., Poliński D.

2008 Naczynia ceramiczne z nawarstwień przedgrodowych w Pniu. Przyczynek do problematyki początków osadnictwa wczesnośredniowiecznego w zachodniej części ziemi chetmińskiej, [w:] Ad Oderam fluvium. Księga dedykowana pamięci Edwarda Dąbrowskiego, red. B. Gruszka, Zielona Góra, s. 351-361.

2011 Wyniki badań wykopaliskowych średniowiecznej warowni w Pniu, gm. Dabrowa Chetmińska, woj. kujawsko-pomorskie (stanowisko 1), przeprowadzonych w latach 2007-2008, [w:] XVII Sesja Pomorzoznawcza, t. 1: Od epoki kamienia do wczesnego średniowiecza, red. M. Fudziński, H. Paner, Gdańsk, s. $489-497$.

Jasiński T.

1992 Okoliczności nadania ziemi chetmińskiej krzyżakom w 1228 roku w świetle dokumentu łowickiego, [w:] Balticum. Studia z dziejów polityki, gospodarki i kultury XII-XVII wieku, ofiarowane Marianowi Biskupowi w siedemdziesiąta rocznicę urodzin, red. Z. H. Nowak, Toruń, s. 151-163.

Jóźwiak S., Szweda A.

2005 List starosty bydgoskiego Janusza Brzozogłowego do wielkiego mistrza Michała Küchmeistra z 27 maja 1418. Przyczynek do pogranicznych stosunków polsko-krzyżackich w końcu drugiej dekady XV wieku, Zapiski Historyczne, t. 70 , z. 2-3, s. 125-134.

Kola A.

1991 Grody ziemi chetmińskiej w późnym średniowieczu, Toruń. Leciejewicz L.

$1959 \quad Z$ badań nad ksztattowaniem się ośrodków grodowych na pograniczu pomorsko-wielkopolskim we wczesnym średniowieczu, Slavia Antiqua, t. 6, s. $134-171$.

Łęga W.

1956 Społeczeństwo i państwo gdańsko-pomorskie w XII i XIII wieku, Poznań.

Mader F.

1960 Der Wald in Altpreussen als Wirtschaftsraum, Köln.

Maleczyński K.

1975 Bolesław III Krzywousty, Wrocław.

Molewski P., Poliński D.

2006 Struktura przestrzenna późnośredniowiecznego osadnictwa wiejskiego ziemi chetmińskiej na tle środowiska fizyczno-geograficznego, Acta Universitatis Nicolai Copernici, Archeologia 30, s. 75-93.

Narbutt T.

1837 Dzieje starożytne narodu litewskiego, t. 2: Śledzenia początków narodu litewskiego i poczatki jego dziejów, Wilno. 
O usadowieniu się Krzyżaków

1848 O usadownieniu się Krzyżaków w Prusiech (Pierwsze 20 lat), Przyjaciel Ludu, R. 15, nr 18, s. 139, 142-144.

Poliński D.

2008 Sprawozdanie z badań wykopaliskowych przeprowadzonych w Pniu w 2008 roku, maszynopis w Instytucie Archeologii UMK, Torun.

Porębska K.

1971 Stownik historyczno-geograficzny ziemi chetmińskiej w średniowieczu, Warszawa.

Powierski J.

1968 Stosunki polsko-pruskie do 1230 roku ze szczególnym uwzględnieniem Pomorza Gdańskiego, Roczniki Towarzystwa Naukowego w Toruniu, R. 74, z. 1, Toruń.

1972 Hugo Butyr. Fragment stosunków polsko-niderlandzkich w XII w., Zapiski Historyczne, t. 37, z. 2, s. 9-43.

1973 Studia nad struktura administracyjno-terytorialna ziemi chetmińskiej i michałowskiej w okresie piastowskim, Prace Wydziału Nauk Humanistycznych Bydgoskiego Towarzystwa Naukowego, seria C, nr 13, s. 3-86.

1993 Początek walk Krzyżaków o panowanie nad Zalewem Wiślanym i założenie Elblaga, Nautologia, R. 28, nr 3, s. 2-22.

2004 Ksztaltowanie sie granicy pomorsko-pruskiej w okresie od XII do poczatku XIV wieku cz. 2, [w:] Prussica. Artykuty wybrane z lat 1965-1995, t. 1, red. J. Trupinda, Malbork, s. 63-80.

Powierski J., Śliwiński B., Bruski K.

1993 Studia z dziejów Pomorza XII wieku, Słupsk.

Rymar E.

1983 Niektóre aspekty dyskusji wokót początków dynastii ksiązęcej na Pomorzu Nadwiślańskim, Rocznik Gdański, t. 43, z. 1, s. 5-45.

Szulc D.

1844 O znaczeniu Prus dawnych, Warszawa.

Ślaski K.

1954 Granica wielkopolsko-pomorska w okresie wczesnego feudalizmu, Przegląd Zachodni, R. 10, z. 1-2, s. 91-107.

1969 Problem zajęcia Ziemi Chetmińskiej przez Prusów, Acta Baltico-Slavica, t. 6, s. 213-218.

Śliwiński B.

1989 Pogranicze kujawsko-pomorskie w XII-XIII wieku. Z dziejów Bydgoskiego $i$ Wyszogrodzkiego w latach 1113-1296, Prace Wydziału Nauk Humanistycznych Bydgoskiego Towarzystwa Naukowego, seria c, nr 32, Warszawa.

Tokarski W.

1994 Wczesnośredniowieczne grodzisko w Rzęczkowie na ziemi chetmińskiej, [w:] Studia nad osadnictwem wczesnośredniowiecznym ziemi chetmińskiej. Wybrane zagadnienia i materiaty, red. J. Olczak, Toruń, s. 83-110. 
Wilke G., Potemski C.

1985 Źródła archeologiczne do studiów nad osadnictwem wczesnośredniowiecznym z terenu Bydgoszczy i powiatu Bydgoskiego, czesść II, Prace Komisji Historii Bydgoskiego Towarzystwa Naukowego, t. 15, s. 3-27.

\section{Zakrzewski S.}

1902 Nadania na rzecz Chrystyana, biskupa pruskiego w latach 1217-1224, Rozprawy Akademii Umiejętności. Wydział Historyczno-Filozoficzny, Serya II, t. 17 , s. 237-332.

\section{QUONDAM CASTRUM PIN IN LIGHT OF RECENT ARCHAEOLOGICAL EXCAVATIONS}

Summary

Archaeological excavations in Pień (Dąbrowa Chełmińska commune) were carried out by the Institute of Archaeology of the Nicolaus Copernicus University in Torun in 2003-2007 and continued in 2008. During this last season the interest of researchers focused on site 1, within which was an early medieval stronghold and, situated directly on its remains, was a late medieval motte.

The stronghold in Pien drew the attention of historians as early as the $19^{\text {th }}$ century due to several medieval documents from 1222, 1247-1248 and 1285. A small amount of data on the history of the locality in the $13^{\text {th }}$ century became the foundation for a wideranging polemic amongst historians. Already from the beginning of the $20^{\text {th }}$ century the possibility of close administrative ties between the stronghold in Pień, the Wyszogród castellany and the Powała family estate with its centre in Pień was pointed out in literature. Another area that was researched was an attempt to clarify the rights to the locality of Świętopełk, Duke of Pomerania and Konrad, Duke of Mazovia.

The main aim of the excavations conducted in 2008 was a comprehensive study of the remains of the Teutonic Order residential-defence feature located on the mound. Two trenches were set: one (trench 9/08), with dimensions of $5 \times 5 \mathrm{~m}$, in the southern part of the motte, and the second (trench 10/08) with dimensions of $4 \times 2 \mathrm{~m}$, on its western slope. In the first trench it was expected that the course of the southern wall of the feature and the location of an annex with a possible entrance would be unearthed. The second trench was set to verify the existence of cultural layers at the edge of the early medieval stronghold and the late medieval motte.

Archaeological excavations carried out over six seasons provided data which complements the existing hypotheses. Four phases of the stronghold occupation in the Early Middle Ages were identified. The researchers failed to link the youngest phase, dated from the $11^{\text {th }}$ century to the $11^{\text {th }} / 12^{\text {th }}$ century, with the recorded remains of the fortifications, hence the hypothesis of the open nature of the settlement in the early $12^{\text {th }}$ century. This suggests that the stronghold in Pień, mentioned in the document from Lonyz as quondam castrum, ceased to have defensive functions at the time when the document was issued by the office of Konrad, Duke of Mazovia. Based on the pottery material, it is assumed that the end of the early medieval settlement in Pien is roughly the turn of the $11^{\text {th }}$ century. However, due to the intensification of hostilities in this part of Polish territory, it is impossible to unequivocally prove who destroyed the stronghold. 